\title{
Keterangan Ahli Warga Negara Asing dalam Peradilan Pidana di Indonesia
}

\author{
Vika Ayu Wandari \\ Airlangga University, Indonesia \\ vikaayu19@gmail.com
}

\begin{abstract}
Proof plays an important role in the process of adjudication in the trial process. In the criminal process, proof requires the attendance of an expert, particularly when it deals with an expert from abroad to provide statements in the courts. This paper aims to show the importance of evidences in the Indonesian criminal law procedure in which the statement to be delivered by an expert from abroad. It will discuss the importance of expert's statement from foreign citizen to help judges in the criminal justice system of Indonesia. To judges, the statement of an expert has a power characterised as free and non-binding evidence by which the judgement fully depends upon judges' conviction. While a foreign citizen arrives in Indonesia designated as an expert to provide witness in the trial process in which he/she does not hold visa, judges cannot dispute his/her absence of visa, but they are only given a power to consider the statement of such expert. With regard to visa, it is not the responsible of judges or the court, but the Immigration Bureau.
\end{abstract}

KEYWORDS: Proof, Evidence, Statement of Expert.

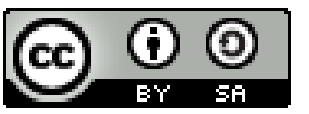

Copyright $\odot 2018$ by Author(s)

International This work is licensed under a Creative Commons Attribution-ShareAlke

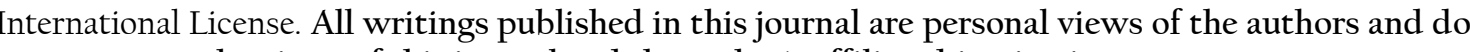
not represent the views of this journal and the author's affiliated institutions.

\section{HOW TO CITE:}

Wandari, Vika Ayu. "Keterangan Ahli Warga Negara Asing dalam Peradilan Pidana di Indonesia" (2018) 5:1 Lentera Hukum 97-114.

Submitted: January 23, 2018 Revised: February 13, 2018 Accepted: March 02, 2018 


\section{PENDAHULUAN}

Perkembangan hukum pidana yang disertai dengan perkembangan hak asasi manusia mempengaruhi pandangan dan pemikiran ahli pidana. Namun, pemikiran dan pembaharuan hukum pidana masih sulit diterapkan dalam sistem hukum pidana di Indonesia, khususnya berkaitan dengan sistem peradilannya. Pelaksanaan pembuktian tidak semata-mata bergantung kepada ketentuan-ketentuan yang mengatur tentang pembuktian itu sendiri, tetapi juga bergantung kepada aparat penegak hukum yang melaksanakannya yaitu polisi sebagai penyelidik dan penyidik, jaksa sebagai peneliti dan penuntut umum, hakim sebagai pimpinan persidangan dan pemutus perkara, tiga rumpun tersebut yang mewakili instansi yang oleh undang-undang diberi kekuasaan dan wewenang penegakan hukum. ${ }^{1}$

Pada dasarnya, pembuktian dalam perkara pidana membuktikan adanya tindak pidana atas kesalahan terdakwa. Dalam praktek pembuktian adalah tindakan penuntut umum untuk meyakinkan hakim atas kesalahan terdakwa berdasarkan barang bukti dan alat bukti yang dihadirkan di muka persidangan. Untuk mengetahui dan mempelajari hubungan antara bukti fisik dengan suatu kasus tindak pidana, diperlukan ahli (pakar), pentingnya pakar atau ahli adalah untuk memperlajari hubungan antara bukti fisik dengan suatu kasus tindak pidana dalam bidang tersebut. ${ }^{2}$

Penelitian ini bertujuan mengetahui pentingnya pembuktian alat bukti keterangan ahli, khusunya alat bukti keterangan ahli warga negara asing dalam proses perkara pidana di Indonesia. Dalam pedoman pelaksanaan Kitab Undang-Undang Hukum Aacara Pidana (KUHAP) telah dijelaskan bahwa tujuan dari penegakan hukum pidana adalah untuk mencari kebenaran materiil. Artinya, KUHAP menghendaki kebenaran yang selengkap-lengkapnya dari suatu perkara pidana dengan menerapkan ketentuan hukum pidana yang diatur secara jujur dan tepat. Terhadap orang yang mampu bertanggung jawab atas perbuatannya, tentu orang tersebut harus mempertanggung-jawabkan perbuatannya. ${ }^{3}$

Berdasarkan latar belakang di atas, tulisan ini mendiskusikan regulasi keterangan ahli warga negara asing dalam persidangan yang mana peraturan tertentu yang diatur oleh pemerintah. Dalam hal ini regulasi antara undang-undang keimigrasian dan KUHAP dalam hukum positif di Indonesia. Keabsahan keterangan ahli warga negara asing menggunakan visa kunjungan.

Hendar Soetarna, Hukum Pembuktian Dalam Acara Pidana, (Bandung: Alumni, Cetakan Pertama, 2011), hlm. 3.

2 R. Soeparmono, Keterangan Ahli $\mho$ Visum Et Repertum Dalam Aspek Hukum Acara Pidana, (Bandung: Mandar Maju, 2002), hlm. 64.

3 Pertanggungjawaban pidana atau kesalahan menurut hukum pidana terdiri dari 3 anasir yaitu pertama, dapat dipertanggungjawabkan dari si pembuat. Kedua, suatu sikap psikis pembuat berhubung dengan kelakuannya yaitu disengaja, dan sikap kurang hati-hati atau lalai. Ketiga, tidak ada alasan-alasan yang menghapuskan peratanggungjawaban pidana bagi pembuat (anasir pertanggungjawaban pidana), dan khusus anasir pertanggungjawaban ini berhubungan erat dengan "kesalahan" dan "melawan hukum" sebab tanpa melawan hukum tidak akan ada kesalahan, Atang Ranoemihardja, hukum pidana, asas-asas hukum pidana, pokok pengertian \& teori serta pendapat para beberapa sarjana, (Bandung: Tarsito, 1984), hlm. 44-45. 


\section{REGULASI KETERANGAN AHLI WARGA NEGARA ASING DALAM PERSIDANGAN}

Istilah ahli didefinisikan oleh S.Tanusubroto, ${ }^{4}$ sebagai orang yang memiliki keahlian khusus tentang hal yang diperlukan untuk membuat terang suatu perkara pidana gunakepentingan pemeriksaan. Ahli dapat pula diartikan sebagai orang yang mahir, paham sekali suatu ilmu atau kepandaian. ${ }^{5}$ Definisi lainnya dapat dilihat pada Black's Law Dictionary, yang mengartikan expert (ahli) yaitu, "one who is knowladgeable in specialized field that knowladge being obtained from either education or personal experience". Maksudnya adalah bahwa ahli adalah seseorang yang berpengetahuan dalam bidang khusus dimana pengetahuan melalui pendidikan maupun pengalaman pribadi). ${ }^{6}$

Poerwadarminta dalam Kamus Umum Bahasa Indonesia memberikan dua pengertian mengenai ahli yaitu orang yang mahir atau paham sekali pada suatu ilmu tertentu (pengetahuan, pandai); misalnya ahli bahasa dan tenaga ahli diartikan sebagai orang (pekerja yang mahir dalam suatu pekerjaan. Sedangkan keahlian adalah kemahiran dalam suatu ilmu (kepandaian, pekerjaan). ${ }^{7}$ Menurut Lucky Raspati, kekeliruan yang sering terjadi dalam proses peradilan di Indonesia adalah keterangan ahli yang dihadirkan oleh para pihak bertujuan untuk kepentingan para pihak itu sendiri. Ilmu pengetahuan dan hakikat keadilan yang disebut Pasal 179 ayat (1) KUHAP seolah terabaikan. Lucky Raspati juga mengatakan bahwa ahli dalam suatu kasus pidana memang harus dilibatkan sejak awal karena tugasnya untuk menganalisis sesuai bidang keilmuan.

Hasil analisis berupa opini dituangkan dalam berita acara pemeriksaan dan berita acara pemeriksaan tersebut masuk ke persidangan. Ahli tersebut boleh memberikan keterangan dalam persidangan untuk membantu hakim, misalnya saja penyebab kematian seseorang. Indonesia tidak memiliki kriteria ahli yang bisa masuk ke persidangan. Terkesan siapa saja bisa menjadi ahli. Bahkan sarjana hukum bisa menjadi ahli untuk menerangkan suatu peraturan, padahal ada prinsip 'hakim dianggap tahu hukum' (ius curia novit). Hakim juga khawatir berimbas pada pelaporan ke Komisi Yudisial jika menolak ahli yang dihadirkan salah satu pihak. Seharusnya sejak awal sudah ada aturan siapa saja yang boleh dijadikan ahli. ${ }^{8}$

Klasifikasi Keterangan Ahli Berdasarkan KUHAP, dalam Pasal 1 angka 28 KUHAP dan Pasal 186 KUHAP. KUHAP tidak mengatur secara khusus mengenai syarat menjadi seorang ahli dalam memberikan keterangan di persidangan. Adapun

\footnotetext{
S. Tanusubroto, Dasar-Dasar Hukum Acara Pidana Cetakan 2, (Bandung: Armico, 1989), hlm. 70.

5 Kamus Besar Bahasa Indonesia (KBBI), hlm. ll. (KBBI) menyebutkan berbagai bidang ahli, yaitu: ahli agama, ahli bahasa, ahli bedah, ahli bumi, ahli fitopologi, ahli geologi, ahli minyak, ahli hadits, ahli hukum, ahli ibadah, ahli ilmu racun, ahli mikologi, ahli multi media,ahli negara, ahli nujum, ahli obat, ahli patung, ahli pikir, ahli purbakala, ahli sejarah, ahli seismologi, ahli sihir, ahli suluk, ahli tafsir, ahli tarikh, ahli tetas).

6 Henry Campbell Black, Black's Law Dictionary, sixth edition (st. Paul : West Publishing Co), 1900, h.578

W. J. S. Poerwadarminta. Kamus Umum Bahasa Indonesia. Jakarta. 1976, hlm. 19.

8 Hukumonline, Kedudukan Ahli dan Pendapatnya dalam Perkara Pidana, http://www.hukumonline.com/berita/baca/lt57bc379b6al54/kedudukan-ahli-dan-pendapatnyadalam-perkara-pidana diakses pada 29 Januari 2018, pukul 18.30 WIB.
} 
yang disebut dalam KUHAP adalah selama ia menjadi saksi ahli yang memiliki 'keahlian khusus' tentang hal yang diperlukan untuk membuat terang suatu perkara pidana dan diajukan oleh pihak-pihak tertentu, maka keterangannya bisa didengar untuk kepentingan pemeriksaan. Keahlian khusus tersebut dapat diperoleh seseorang baik melalui pendidikan formal maupun non-formal, dan bisa juga melalui sertifikasi dalam bidang terkait keahlian serta pengalaman-pengalaman yang dimiliki.

Hakim bebas menilai dan tidak ada keharusan bagi Hakim untuk menerima kebenaran keterangan ahli tersebut, akan tetapi Hakim di dalam mempergunakan wewenang kebebasan dan penilaian pembuktian, harus benar-benar bertanggung jawab atas landasan moral demi terwujudnya kebenaran dan demi tegaknya hukum serta kepastian hukum. ${ }^{9}$ Keterangan ahli bersifat menguatkan keyakinan hakim. Kekuatan alat bukti keterangan ahli bersifat bebas karena tidak mengikat seorang hakim untuk memakainya apabila bertentangan dengan keyakinannya. Fungsi dari keterangan ahli di persidangan merupakan alat bantu hakim untuk menemukan kebenaran dan hakim bebas mempergunakan sebagai pendapatnya sendiri atau tidak. Jika keterangan ahli tersebut bertentangan, bisa saja dikesampingkan oleh hakim. Yang perlu diingat apabila keterangan ahli dikesampingkan harus berdasarkan alasan yang jelas.

Mengenai nilai kekuatan pembuktian yang melekat pada keterangan ahli bersifat bebas dan tidak mengikat hakim. Nilai kekuatan pembuktian pada ketengan ahli sama denganseperti nilai kekuatan pembuktian yang lainnya juga. Nilai kekuatan pembuktian yang melekat pada alat bukti keterangan ahli, yaitu mempunyai nilai kekuatan pembuktian "bebas" atau "vrij bewijskracht" artinya tidak ada yang melekat atau tidak ada yang sempurna dan menentukan. Hakim bebas menilainya dan tidak terikat.

Pada Undang-Undang Nomor 6 Tahun 2011 tentang Keimigrasian mengatur tentang lalu lintas orang yang masuk atau keluar negara Republik Indonesia serta pengawasan untuk menjaga tegaknya kedaulatan negara. Imigrasi memiliki peranan penting dalam mencegah tindak pidana transnasional seperti perdagangan orang, penyelundupan manusia, dan tindak pidana narkotika yang banyak dilakukan oleh sindikat Internasional. Disatu sisi sebagai bagian dari sistem hukum administrasi negara, hukum keimigrasian sering disertai dengan sanksi pidana. ${ }^{10}$ Regulasi ini mewajibkan setiap orang asing yang berada di wilayah Indonesia wajib memiliki izin tinggal. ${ }^{11}$ Selanjutnya diatur pula bahwa visa tinggal terbatas diberikan kepada orang asing yang salah satunya tugas sebagai tenaga ahli yang akan melakukan perjalanan ke wilayah Indonesia untuk bertempat tinggal dalam jangka waktu yang terbatas. ${ }^{12}$

\footnotetext{
9 M. Yahya Harahap, Pembahasan Permasalahan dan Penerapan KUHAP Pemeriksaan Sidang Pengadilan, Banding, Kasasi, dan Peninjauan Kembali (Jakarta: Sinar Grafika, 2010), hlm. 304-305.

10 Jasim Hamidi \&\& Charles Christian, Hukum Keimigrasian Bagi Orang Asing di Indonesia, (Jakarta: Sinar Grafika, 2015), hlm. 9

Il Pasal 48 Undang-Undang Nomor 6 Tahun 2011 tentang Keimigrasian.

12 Pasal 39 Undang-Undang Nomor 6 Tahun 2011 tentang Keimigrasian..
} 
Pasal 102 ayat (2) huruf a Peraturan Pemerintah Nomor 31 Tahun 2013 Tentang Peraturan Pelaksanaan Undang-Undang Nomor 6 Tahun 2011 Tentang Keimigrasian menjelaskan bahwa visa tinggal terbatas hanya diberikan kepada tenaga ahli yang dalam rangka bekerja di wilayah Negara Indonesia. Dalam Surat Edaran Dirjen Pajak Nomor 39/PJ.23/1984 pengertian tenaga ahli adalah orang pribadi yang mempunyai keahlian khusus yang dalam memberikan jasa berdasarkan keahliannya dan tidak terikat oleh hubungan kerja (melakukan pekerjaan bebas/memberikan professional services), misalnya dokter, pengacara, notaris dan lain-lain. Secara umum, tenaga ahli adalah seseorang yang memiliki pengetahuan atau kemampuan dalam bidang studi tertentu. Para tenaga ahli didengar pendapatnya dalam bidang terkait yang mereka kuasai, namun mereka tidak selalu setuju dalam kekhususan bidang studi. Keahlian tersebut didapat melalui pelatihan, pendidikan, profesi, publikasi, maupun pengalaman. Seorang tenaga ahli dipercaya memiliki pengetahuan khusus dalam bidangnya di atas rata-rata orang lain. ${ }^{13}$ Di samping itu, dalam Pasal 102 ayat (2) huruf d Peraturan Pemerintah Nomor 31 Tahun 2013 Tentang Keimigrasian diatas, dijelaskan bahwa visa tinggal terbatas hanya diberikan kepada saksi ahli yang berkaitan dengan profesinya menerima bayaran.

Tindakan keimigrasian dibagi menjadi dua macam, yaitu tindakan administrasi keimigrasian dan tindakan pidana. Tindakan administrasi keimigrasian adalah sanksi administrasi yang ditetapkan oleh pejabat imigrasi terhadap orang asing diluar proses pengadilan, sedangkan tindak pidana adalah sanksi yang ditetapkan oleh pejabat administrasi terhadap orang asing melalui proses pengadilan.

Tindakan keimigrasian dilakukan oleh pejabat imigrasi. ${ }^{14}$ Dalam melaksanakan tugas melakukan tindakan kemigrasian berupa tindakan adminitrasi keimigrasian, dimana pejabat Imigrasi berwenang melakukan tindakan administratif keimigrasian. ${ }^{15}$ Tindakan administrasi keimigrasian dapat berupa mencantumkan daftar pencegahan, pembatasan, perubahan atau pembatalan izin tinggal, larangan berada di wilayah tempat tertentu di Indonesia, keharusan bertempat tinggal di suatu tempat di wilayah Indonesia, pengenaan biaya beban, dan di deportasi dari wilayah Indonesia. ${ }^{16}$

Orang asing yang masuk wilayah Republik Indonesia harus memiliki visa yang sah dan masih berlaku memiliki dokumen perjalanan yang sah dan masih berlaku dan tidak termasuk dalam daftar panangkalan (pencekalan). Pejabat Imigrasi berhak menolak orang asing masuk ke wilayah Republik Indonesia apabila namanya tercantum dalam daftar pencekalan, tidak memiliki dokumen perjalanan yang sah dan tidak memiliki visa. Pejabat Imigrasi juga berhak melakukan tindakan keimigrasian berupa tindakan administratif keimigrasian berupa deportasi dari wilayah Indonesia berdasarkan Undang-Undang Keimigrasian apabila seorang ahli tersebut dalam

\footnotetext{
13 Hukumonline, Arti Catat Hukum, http://www.hukumonline.com/klinik/detail/lt556fa8a2bllo0/articacat-hukum-diakses pada ll Desember 2017, pukul 11.20 WIB.

14 Pasal 1 angka 7 Undang-Undang Nomor 6 Tahun 2011 tentang Keimigrasian..

15 Pasal 75 ayat (1) Undang-Undang Nomor 6 Tahun 2011 tentang Keimigrasian.

16 Pasal 75 ayat (2) Undang-Undang Nomor 6 Tahun 2011 tentang Keimigrasian..
} 
memberikan keterangannya di muka persidangan dalam kondisi ia tidak mengurus visa berdasarkan Undang-Undang Keimigrasian yang berlaku.

Apabila seorang ahli warga negara asing dalam memberikan keterangannya di muka persidangan dalam kondisi ia tidak mengurus visa berdasarkan Undang-Undang Keimigrasian yang berlaku, dapat dikatakan seorang ahli tersebut merupakan warga negara asing ilegal karena melanggar ketentuan visa sebagaimana Undang-Undang Keimigrasian. Meskipun, tidak terdapat dampak kekuatan kesaksian terhadap pelanggaran mengenai ketentuan visa.

Pada dasarnya seorang ahli warga negara asing yang dihadirkan adalah untuk menjernihkan suatu masalah. Seorang ahli warga negara asing telah melanggar ketentuan visa yang telah ditentukan dan mendapat sanksi administrasi berupa deportasi atau bahkan sanksi pidana, hanya saja seorang ahli warga negara asing tersebut hanya melanggar ketentuan visa dan tidak dianggap membahayakan, seorang ahli warga negara asing tersebut hanya diterapkan sanksi administrasi keimigrasian sesuai dengan Pasal 75 Undang-Undang Nomor 6 Tahun 2011 Tentang Keimigrasian. Seorang ahli warga negara asing yang didatangkan ke negara Indonesia harus berdasarkan panggilan dan hubungan kerja antar kedua negera. Hubungan kerja adalah hubungan antara pengusaha dengan pekerja/buruh berdasarkan perjanjian kerja, yang mempnyai unsur pekerjaan, upah, dan perintah. ${ }^{17}$ Diliat dari pengaturan kehadiran seorang ahli dalam memberikan keterangan di persidangan tidak secara tegas mengatur tentang visa yang digunakan seorang ahli untuk memberikan keterangan di muka persidangan. Visa yang digunakan oleh seorang ahli warga negara asing hanya menggunakan visa kunjungan, hal ini jelas tidak sesuai dengan kapasitasnya sebagai seorang ahli yang dihadirkan di muka persidangan.

Sistem peradilan pidana dan hukum acara pidana, khususnya pada aspek pembuktian memegang peranan penting dalam persidangan guna menemukan dan menyatakan kesalahan seseorang sehingga dijatuhkan pidana oleh hakim. Apabila dilihat dari letaknya dalam kerangka yuridis aspek pembuktian terbilang unik karena dapat diklarifikasikan dalam hukum pidana formal maupun hukum pidana materiil. ${ }^{18}$

Pembuktian juga merupakan ketentuan yang mengatur alat-alat bukti yang dibenarkan undang-undang dan mengatur mengenai alat bukti yang boleh digunakan hakim guna membuktikan kesalahan terdakwa. ${ }^{19}$ Menurut M. Yahya Harahap Sistem teori pembuktian sebagai berikut Conviction-in Time (sistem atau teori pembuktian berdasarkan keyakinan hakim saja) dimana salah tidaknya seorang terdakwa berdasarkan penilaian keyakinan hakim. Keyakinan boleh diambil dan disimpulkan hakim dari alat-alat bukti yang diperiksanya dalam sidang pengadilan. ${ }^{20}$ ConvictionRaisonee (sistem atau teori pembuktian berdasarkan keyakinan hakim atas alasan yang logis) dimana keyakinan hakim didukung dengan alasan yang jelas. Hakim wajib

\footnotetext{
Pasal 1 angka 14 Undang-Undang Nomor 13 Tahun 2003 tentang Ketenagakerjaan.

Lilik Mulyadi, Pembalikan Baban Pembuktian Tindak Pidana Korupsi, (Bandung: PT. Alumni, 2013), hlm. 83.

19 M. Yahya Harahap, supra note 9 hlm. 277-279.

20 Ibid.
} 
menguraikan dan menjelaskan alasan-alasan apa yang mendasari keyakinannya atas kesalahan terdakwa. Keyakinan hakim harus mempunyai dasar-dasar yang logis dan benar-benar dapat diterima akal. ${ }^{21}$ Positive Wettelijk Bewijstheorie (sistem atau teori pembuktian menurut undang-undang secara positif) dimana keyakinan hakim dalam sistem ini tidak ikut berperan menentukan salah atau tidaknya terdakwa. Sistem ini berpedoman pada prinsip pembuktian dengan alat-alat bukti yang ditentukan oleh undang-undang. Negatief Wettelijk Stelsel (Pembuktian Menurut Undang-Undang Secara Negatif) dimana Sistem pembuktian menurut undang-undang secara negatif merupakan teori antara sistem pembuktian menurut undang-undang secara positif dengan sistem pembuktian menurut keyakinan hakim atau conviction-in time. Rumusannya berbunyi salah tidaknya seorang terdakwa ditentukan oleh keyakinan hakim yang didasarkan kepada cara dan dengan alat-alat bukti yang sah menurut undang-undang. ${ }^{22}$

Didik Endro membagi teori pembuktian menjadi 4 (empat) kelompok yakni teori pembuktian berdasarkan undang-undang secara positif (postief wettelijke bewijs theorie), teori pembuktian berdasarkan keyakinan hakim saja (conviction intime) teori pembuktian keyakinan hakim atas alasan yang logis (Laconviction Raisonnee), dan teori pembuktian undang-undang secara negatif (Negatief wettelijk bewijs theotrie). ${ }^{23}$

Peradilan Indonesia telah lama menggunakan sistem atau teori pembuktian berdasarkan undang-undang secara negatif (negative Wettelijk). Dalam sistem ini ada 2 (dua) hal yang merupakan syarat untuk membuktikan kesalahan terdakwa, yaitu Wettelijk, yaitu adanya alat bukti yang sah yang telah ditetapkan oleh undang-undang, dan Negative, yaitu adanya keyakinan (nurani) hakim yakni berdasarkan bukti-bukti tersebut hakim meyakini kesalahan terdakwa. ${ }^{24}$

KUHAP telah memakai sistem pembuktian menurut undang-undang yang negatif, sehingga dalam pembuktian yang dilakukan dengan teliti. Menurut Wirjono Prodikoro bahwa sistem pembuktian berdasarkan undang-undang secara negatif dipertahankan, pertama memang sudah selayaknya harus ada keyakinan hakim tentang kesalahan terdakwa untuk dapat menjatuhkan suatu hukuman pidana, janganlah hakim terpaksa memidana seseorang sedangkan hakim tidak yakin atas kesalahan. ${ }^{25}$ Kedua, keterangan ahli merupakan alat bukti yang sah menurut KUHAP, sehingga hakim bisa menggunakan alat bukti keterangan ahli didalam persidangan, untuk meyakinkan hakim bahwa terdakwa melakukan tindak pidana atau tidak.

Di dalam KUHAP, alat bukti berupa keterangan ahli sudah dikenal. Hal ini tidak dihilangkan oleh tim pembuat rancangan undang-undang hukum acara pidana.

$21 \quad$ Ibid, hlm. 277.

22 Ibid., hlm. 279.

23 Didik Endro Purwoleksono, Hukum Acara Pidana, (Surabaya: Airlangga University Press, 2015), hlm. $123-124$

24 M. Yahya Harahap, supra note $9 \mathrm{hlm} .17$.

25 Andi Hamzah, Pengantar Hukum Acara Pidana Indonesia, (Jakarta: Ghalia Indonesia, 1985), hlm. 257. 
Mengenai beberapa pengaturan dalam KUHAP dan R-KUHAP tentang keterangan ahli dapat dilihat dalam tabel berikut:

\begin{tabular}{|c|c|}
\hline KUHAP & R-KUHAP \\
\hline $\begin{array}{l}\text { Keterangan ahli adalah keterangan yang } \\
\text { diberikan oleh seorang yang memiliki keahlian } \\
\text { khusus tentang hal yang diperlukan untuk } \\
\text { membuat terang suatu perkara pidana guna } \\
\text { kepentingan pemeriksaan (Pasal l angka 28). }\end{array}$ & $\begin{array}{l}\text { Ahli adalah seorang yang mempunyai keahlian } \\
\text { tertentu yang diperlukan untuk membuat terang } \\
\text { suatu perkara pidana guna kepentingan } \\
\text { penyidikan, penuntutan, dan pemeriksaan di } \\
\text { sidang pengadilan (Pasal l angka 27). }\end{array}$ \\
\hline $\begin{array}{l}\text { (1) Dalam hal penyidik menganggap perlu, ia } \\
\text { dapat minta pendapat orang ahli atau orang } \\
\text { yang memiliki keahlian khusus. } \\
\text { (2) AhIi tersebut mengangkat sumpah atau } \\
\text { mengucapkan janji di muka penyidik bahwa } \\
\text { ia akan memberi keterangan menurut } \\
\text { pengetahuannya yang sebaik-baiknya kecuali } \\
\text { bila disebabkan karena harkat serta martabat, } \\
\text { pekerjaan atau jabatannya yang mewajibkan } \\
\text { ia menyimpan rahasia dapat menolak untuk } \\
\text { memberikan keterangan yang diminta (Pasal } \\
\text { 120) }\end{array}$ & $\begin{array}{l}\text { (1) Dalam hal penyidik menganggap perlu, } \\
\text { penyidik dapat meminta pendapat ahli. } \\
\text { (2) Sebelum memberikan keterangan, ahli } \\
\text { mengangkat sumpah atau mengucap janji di } \\
\text { muka penyidik untuk memberikan } \\
\text { keterangan menurut pengetahuannya dengan } \\
\text { sebaik-baiknya. } \\
\text { (3) Jika ahli yang karena harkat dan martabat, } \\
\text { pekerjaan, atau jabatan diwajibkan } \\
\text { menyimpan rahasia, maka ahli dapat } \\
\text { menolak untuk memberikan keterangan yang } \\
\text { diminta (Pasal 25). }\end{array}$ \\
\hline $\begin{array}{l}\text { (1) Setiap orang yang diminta pendapatnya } \\
\text { sebagai ahli kedokteran kehakiman atau } \\
\text { dokter atau ahli lainnya wajib memberikan } \\
\text { keterangan ahli demi keadilan. } \\
\text { (2) Semua ketentuan tersebut di atas untuk saksi } \\
\text { berlaku juga bagi mereka yang memberikan } \\
\text { keterangan ahli dengan ketentuan bahwa } \\
\text { mereka mengucapkan sumpah atau janji akan } \\
\text { memberikan keterangan yang sebaik-baiknya } \\
\text { dan yang sebenarnya menurut pengetahuan } \\
\text { dalam bidang keahliannya (Pasal l79). }\end{array}$ & $\begin{array}{l}\text { (1) Setiap orang yang diminta pendapatnya } \\
\text { sebagai ahli kedokteran kehakiman atau } \\
\text { dokter atau ahli lainnya wajib memberikan } \\
\text { keterangan ahli demi keadilan. } \\
\text { (2) Semua ketentuan mengenai saksi, berlaku } \\
\text { juga bagi ahli yang mengucapkan sumpah } \\
\text { atau janji tersebut akan memberikan } \\
\text { keterangan yang sebenar-benarnya dan } \\
\text { sejujur-jujurnya menurut pengetahuan dalam } \\
\text { bidang keahliannya (Pasal 169). }\end{array}$ \\
\hline $\begin{array}{l}\text { Keterangan ahli ialah apa yang seorang ahli } \\
\text { nyatakan di sidang pengadilan (Pasal 186). }\end{array}$ & $\begin{array}{l}\text { Keterangan ahli sebagaimana yang dimaksud } \\
\text { dalam Pasal } 175 \text { ayat (l) huruf d adalah segala hal } \\
\text { yang dinyatakan oleh seseorang yang memiliki } \\
\text { keahlian khusus, di sidang pengadilan (Pasal 179). }\end{array}$ \\
\hline
\end{tabular}


(1) Dalam hal penyidik untuk kepentingan peradilan menangani seorang korban baik luka, keracunan ataupun mati yang diduga karena peristiwa yang merupakan tindak pidana, ia berwenang mengajukan permintaan keterangan ahli kepada ahli kedokteran kehakiman atau dokter dan atau ahli lainnya.

(2) Permintaan keterangan ahli sebagaimana dimaksud dalam ayat (l) dilakukan secara tertulis, yang dalam surat itu disebutkan dengan tegas untuk pemeriksaan luka atau pemeriksaan mayat dan atau pemeriksaan bedah mayat.

(3) Mayat yang dikirim kepada ahli kedokteran kehakiman atau dokter pada rumah sakit harus diperlakukan secara baik dengan penuh penghormatan terhadap mayat tersebut dan diberi label yang memuat identitas mayat, dilak dengan diberi cap jabatan yang dilekatkan pada ibu jari kaki atau bagian lain badan mayat (Pasal 133).
(1) Dalam hal Penyidik untuk kepentingan peradilan korban luka, keracunan, atau mati yang diduga akibat peristiwa tindak pidana, penyidik berwenang mengajukan permintaan keterangan kepada ahli kedokteran kehakiman atau dokter dan/atau ahli lainnya.

(2) Permintaan keterangan ahli sebagaimana dimaksud ayat (1) dilakukan secara tertulis dengan menyebutkan secara tegas untuk pemeriksaan luka, keracunan, mayat, dan/atau bedah mayat.

(3) Dalam hal korban mati, mayat dikirim kepada ahli kedokteran kehakiman dan/atau dokter pada rumah sakit dengan memperlakukan mayat tersebut secara baik dengan penuh penghormatan dan diberi label yang dilak dan diberi cap jabatan yang memuat identitas mayat dan dilekatkan pada ibu jari kaki atau bagian lain bada mayat (Pasal 37).

Dalam tabel perbandingan antara Kitab Undang-Undang Hukum Acara Pidana dengan Rancangan Undang-Undang Hukum Acara Pidana terdapat beberapa perbedaan dan ada pula beberapa redaksi yang dipertahankan. Misalnya penggunaan istilah "keterangan ahli" dan "ahli". Kitab Undang-Undang Hukum Acara Pidana, dalam Pasal 1 angka 28, mempergunakan istilah "keterangan ahli". Keterangan ahli ini dipergunakan untuk membuat terang suatu perkara pidana guna kepentingan pemeriksaan.

\section{KEABSAHAN KETERANGAN AHLI WARGA NEGARA ASING MENGGUNAKAN VISA KUNJUNGAN}

Penggunaan istilah criminal justice system atau sistem peradilan pidana (SPP) kini telah menjadi istilah yang menunjukan mekanisme kerja dalam penanggulangan kejahatan dengan menggunakan dasar pendekatan sistem. Sistem peradilan pidana adalah pemakaian sistem terhadap mekanisme administrasi peradilan pidana dan peradilan pidana sebagai suatu sistem merupakan hasil interaksi antara peraturan perundang-undangan, praktek administrasi dan sikap tingkah laku sosial. ${ }^{26}$

Menurut Romli Atmasasmita, pengertian sistem itu sendiri mengandung implikasi suatu proses yang dipersiapkan secara rasional dan dengan cara efisien untuk memberikan hasil tertentu dengan segala keterbatasannya. ${ }^{27}$ Menurut Hagan

\footnotetext{
${ }^{26}$ Ibid, hlm. 3.

27 Romli Atmasasmita, Sistem Peradilan Pidana Kontemporer, (Jakarta: Kencana Prenada Media Group, 2010), hlm. 2.
} 
sebagaimana dikutib Romli Atmasasmita dalam bukunya berjudul "Sistem Peradilan Pidana Kontemporer" memberikan pandangan lain dengan membedakan pengertian criminal justice process dan ciminal justice system. Criminal justice process adalah setiap tahap dari suatu putusan yang menghadapkan seorang tersangka ke dalam proses yang membawanya kepada penentuan pidana baginya. Sedangkan criminal justice system adalah interkoneksi antara keputusan dari setiap instansi yang terlibat dalam proses peradilan pidana. Upaya Hagan untuk membedakan antara proses peradilan pidana dengan sistem peradilan pidana pada dasarnya tidak terlalu relevan karena sistem peradilan itu sendiri sudah mencakup proses peradilan pidana. Adanya keterhubungan antara keputusan yang diambil setiap aparat penegak hukum merupakan rangkaian proses peradilan pidana. ${ }^{28}$

Menurut Mardjono mengemukakan pengertian sistem peradilan pidana dengan memberikan batasan bahwa yang dimaksud dengan sistem peradilan adalah sistem pengendalian kejahatan yang terdiri dari lembaga-lembaga kepolisian, kejaksaan, pengadilan, dan pemasyarakatan terpidana. ${ }^{29}$ Lebih sederhana lagi, Madjono mengemukakan bahwa sistem peradilan pidana adalah sistem dalam suatu masyarakat untuk menanggulangi masalah kejahatan. ${ }^{30}$

Bahwa sistem penegakan hukum dalam terjadinya tindak pidana yang dilakukan melalui pendekatan peradilan pidana secara rasional sesuai dengan peraturan perundang-undangan guna mencapai suatu putusan pidana. Di negara Indonesia sistem peradilan pidana mengacu pada kodifikasi hukum pidana formil yaitu Undang-Undang Nomor 8 Tahun 1981 Tentang Kitab Undang-Undang Hukum Acara Pidana (KUHAP).

Ketentuan mengenai keterangan ahli dalam KUHAP tidak diatur secara spesifik dan berurutan pada satu bab, melainkan berada dalam sejumlah pasal yang terpencar. Pasal-pasal tersebut antara lain dapat dilihat dari tabel berikut:

Tabel 1 Pasal-Pasal dalam KUHAP yang mengatur keterangan ahli

\begin{tabular}{|l|l|}
\hline \multicolumn{1}{|c|}{ Pasal } & \multicolumn{1}{c|}{ Isi } \\
\hline Pasal 1 butir 28 & Pengertian tentang Keterangan ahli \\
\hline Pasal 65 & Tersangka atau terdakwa berhak mengajukan ahli yang menguntungkan \\
\hline $\begin{array}{c}\text { Pasal } 120 \text { ayat } 1 \\
\text { ayat } 2\end{array}$ & $\begin{array}{l}\text { Penyidik dapat meminta pendapat ahli } \\
\text { ahli mengucapkan sumpah atau janji di muka penyidik } \\
\text { ahli dapat menolak memberikan keterangan }\end{array}$ \\
\hline Pasal 132 ayat 1 & $\begin{array}{l}\text { Penyidik dapat meminta keterangan ahli dalam hal diterima pengaduan bahwa } \\
\text { sesuatu surat atau tulisan palsu atau dipalsukan atau diduga palsu }\end{array}$ \\
\hline Pasal 133 ayat 1 & $\begin{array}{l}\text { Penyidik dapat meminta keterangan ahli kedokteran kehakiman untuk } \\
\text { mengangani korban luka, keracunan ataupun mati yang diduga karena tindak }\end{array}$ \\
\hline
\end{tabular}

28 Ibid.

29 Mardjono Reksodipoetro, Sistem Peradilan Pidana Indonesia (Melihat pada kejahatan dan penegakan hukum dalam batas-batas toleransi : Pidato Pengukuhan Penerimaan Jabatan Guru Besar tetap dalam Ilmu Hukum pada Fakultas Hukum Universitas Indonesia, Jakarta, 1993, hlm. 1 dalam buku Romli Atmasasmita, Sistem Peradilan Pidana Kontemporer, (Jakarta: Kencana Prenada Media Group, 2010), hlm. 3.

30 Mardjono Reksodipoetro, Hak-Hak Asasi Manusia Dalam Sistem Peradilan Pidana, Pusat Pelayanan Keadilan dan Pengabdian Hukum Universitas Indonesia, 1994, hlm. 84-85 (Mardjono II) 


\begin{tabular}{|c|c|}
\hline $\begin{array}{l}\text { ayat } 2 \\
\text { ayat } 3\end{array}$ & $\begin{array}{l}\text { pidana } \\
\text { Permintaan keterangan ahli dilakukan secara tertulis } \\
\text { Perlakuan terhadap mayat yang dikirim kepada ahli kedokteran kehakiman } \\
\text { atau dokter di rumah sakit }\end{array}$ \\
\hline Pasal 161 ayat 1 & $\begin{array}{l}\text { Pemeriksaan tetap dilakukan meski saksi atau ahli tanpa alasan yang sah } \\
\text { menolak untuk bersumpah atau mengucapkan janji. Hakim dapat } \\
\text { mengeluarkan penetapan untuk mengenakan sandera di rutan negara. } \\
\text { Keterangan saksi atau ahli yang menolah bersumpah atau mengucapkan janji } \\
\text { merupakan keterangan yang dapat menguatkan keyakinan hakim di } \\
\text { persidangan. }\end{array}$ \\
\hline $\begin{array}{c}\text { Pasal } 179 \text { ayat } 1 \\
\text { ayat } 2\end{array}$ & $\begin{array}{l}\text { Ahli kedokteran kehakiman atau ahli lainnya wajib memberi keterangan demi } \\
\text { keadilan. } \\
\text { Kewajiban itu juga berlaku bagi mereka yang memberikan keterangan ahli } \\
\text { dengan mengucapkan sumpah atau janji. }\end{array}$ \\
\hline $\begin{array}{c}\text { Pasal } 180 \text { ayat } 1 \\
\text { ayat } 2\end{array}$ & $\begin{array}{l}\text { Hakim ketua wajib meminta keterangan ahli. } \\
\text { Keberatan yang beralasan dari terdakwa atau penasehat hukum terhadap hasil } \\
\text { keterangan ahli. } \\
\text { Penelitian ulang atas keterangan ahli yang menimbulkan keberatan. } \\
\text { Penelitian ulang dilakukan oleh instansi semula atau instansi lain yang } \\
\text { mempunyai wewenang }\end{array}$ \\
\hline Pasal 184 ayat 1 & Keterangan ahli sebagai alat bukti yang sah \\
\hline Pasal 186 & Pengertian keterangan ahli dalam sidang pengadilan \\
\hline Pasal 229 ayat 1 & $\begin{array}{l}\text { Hak saksi dan ahli untuk mendapat penggantian biaya menurut perundang- } \\
\text { undangan yang berlaku. } \\
\text { Pejabat yang melakukan pemanggilan ahli wajib memberitahukan hak ahli atas } \\
\text { penggantian biaya. }\end{array}$ \\
\hline
\end{tabular}

Keberadaan pasal-pasal mengenai keterangan ahli yang terpencar-pencar tersebut, Yahya Harahap memandang persoalan keterangan ahli terutama sebagai alat bukti tidak bisa dipahami hanya dengan bertumpu pada pasal dan penjelaskan Pasal 186 KUHAP. $^{31}$ Dalam pedoman pelaksanaan KUHAP yang dikeluarkan oleh Menteri Kehakiman melalui Keputusan Menteri Kehakiman Nomor M.14-PW.07.03 Tahun 1983 tentang Tambahan Pedoman Pelaksanaan Kitab Undang-Undang Hukum Acara Pidana, kebenaran materiil diartikan, “...ialah kebenaran yang selengkap-lengkapnya dari suatu perkara pidana dengan menerapkan ketentuan hukum acara pidana secara jujur dan tepat dengan tujuan untuk mencari siapakah pelaku yang dapat didakwakan melakukan suatu pelanggaran hukum, dan selanjutnya meminta pemeriksaan dan putusan dari pengadilan guna menemukan apakah terbukti bahwa suatu tindak pidana dilakukan dan apakah orang yang didakwa itu dapat dipersalahkan. ${ }^{32}$

Tabel 2 Perbedaan keterangan ahli dan keterangan saksi ${ }^{33}$

\begin{tabular}{|l|l|l|}
\hline & \multicolumn{1}{|c|}{ Keterangan Ahli } & \multicolumn{1}{c|}{ Keterangan Saksi } \\
\hline $\begin{array}{l}\text { Dari segi } \\
\text { subjeknya }\end{array}$ & $\begin{array}{l}\text { Tidak semua orang dapat memberikan } \\
\text { keterangan, hanya orang-orang tertentu }\end{array}$ & $\begin{array}{l}\text { Diberikan kepada setiap orang, tidak } \\
\text { terbatas pada siapapun yang penting ia }\end{array}$ \\
\hline
\end{tabular}

31 M. Yahya Harahap, supra note 4 , hlm. 276.

32 Andi Hamzah, supra note 2, hlm. 8-9.

33 Rusli Muhammad, Hukum Acara Pidana Kontemporer, (Bandung: Citra Aditya Bakti, 2007), hlm. 153. 


\begin{tabular}{|l|l|l|l|}
\hline & $\begin{array}{l}\text { yang dapat memberikan keterangan } \\
\text { yaitu bagi mereka yang memiliki } \\
\text { pengetahuan khusus tentang } \\
\text { permasalahan yang dihadapi. }\end{array}$ & $\begin{array}{l}\text { melihat, mengetahui dan mengalami } \\
\text { sendiri tentang kejahatan yang } \\
\text { diperiksa. }\end{array}$ \\
\hline $\begin{array}{l}\text { Dari segi } \\
\text { keterangannya }\end{array}$ & $\begin{array}{l}\text { Hanya merupakan pendapat seorang ahli } \\
\text { tentang suatu masalah yang ditanyakan. }\end{array}$ & $\begin{array}{l}\text { Yang disampaikan adalah peristiwa dan } \\
\text { kejadian yang berhubungan langsung } \\
\text { dengan kejahatan yang terjadi. }\end{array}$ \\
\hline $\begin{array}{l}\text { Dari segi } \\
\text { sumpah }\end{array}$ & $\begin{array}{l}\text { Saya bersumpah bahwa akan } \\
\text { memberikan keterangan yang } \\
\text { sebenarnya tidak lain dari yang } \\
\text { sebenarnya. }\end{array}$ & $\begin{array}{l}\text { Saya bersumpah akan memberikan } \\
\text { keterangan yang sebaik-baiknya tidak } \\
\text { lain daripada yang sebaik-baiknya. }\end{array}$ \\
\hline
\end{tabular}

Terhadap perkara pidana di Indonesia secara formil kekuatan pembuktian keterangan ahli tidak mengikat hakim. Hal ini sejalan dengan sistem pembuktian yang dianut dalam peradilan pidana, yaitu pembuktian menurut undang-undang secara negatif. Hakim bebas menilai dan tidak terikat pada keterangan ahli. Nilai kekuatan pembuktian yang melekat pada alat bukti keterangan ahli, yaitu mempunyai nilai kekuatan pembuktian "bebas" atau "vrij bewiskracht". Di dalam dirinya tidak ada melekat nilai kekuatan pembuktian yang sempurna dan menentukan, terserah pada penilaian hakim. Hakim bebas menilainya dan tidak terikat kepadanya, tidak ada keharusan bagi hakim untuk mesti menerima kebenaran keterangan ahli dimaksud. Akan tetapi, hakim dalam mempergunakan wewenang kebabasan dan penilaian pembuktian, harus benarbenar bertanggung jawab, atas landasan moral demi terwujudnya kebenaran sejati dan demi tegaknya hukum serta kepastian hukum.

Di samping itu, sesuai prinsip minimum pembuktian yang diatur dalam Pasal 183 KUHAP, keterangan ahli yang berdiri sendiri saja tanpa didukung oleh salah satu alat bukti yang lain, tidak cukup dan tidak memadai membuktikan kesalahan terdakwa. Apalagi jika Pasal 183 KUHAP dihubungkan dengan ketentuan Pasal 185 ayat (2) KUHAP, yang menegaskan seorang saksi saja tidak cukup untuk membuktikan kesalahan terdakwa. Prinsip inipun berlaku untuk alat bukti keterangan ahli. Bahwa keterangan seorang ahli saja tidak cukup membuktikan kesalahan terdakwa. oleh karena itu, agar keterangan ahli dapat dianggap cukup membuktikan kesalaan terdakwa harus disertai dengan alat bukti lain. ${ }^{34}$

Keterangan ahli mempunyai peranan sangat menentukan, karena dari keterangan tersebut dapat ditentukan warga negara asing tersebut telah memberikan keterangan dengan benar atau tidak. Secara materiil hakim harus lebih teliti dengan pendapat keterangan ahli yang dihadirkan di persidangan. Hakim dalam menjatuhkan putusan pemidanaan (veroordeling) apabila perbuatan yang didakwakan kepada terdakwa terbukti secara sah dan meyakinkan yang didasarkan pada minimum dua alat bukti sebagaimana diamanatkan Pasal 183 KUHAP yang menyebutkan : "hakim tidak boleh menjatuhkan kepada seorang kecuali apabila dengan sekurang-kurangnya mininal dua alat bukti yang sah dan keyakinan hakim, ia memperoleh keyakinan bahwa suatu

34 M. Yahya Harahap, supra note 5 hlm. 304. 
tindak pidana benar-benar terjadi dan bahwa terdakwalah yang bersalah melakukannya".

Warga Negara Asing merupakan seseorang yang tinggal dan menetap di sebuah negara tertentu namun bukan berasal dari negara tersebut. Pengakuan kedudukan warga negara asing tersebut sebagai penduduk di negara Indonesia tertera dalam Pasal 13 Undang-Undang Nomor 3 Tahun 1946 Tentang Warga Negara dan Penduduk Negara. Dalam hal ini orang asing atau Warga Negara Asing tersebut yang tinggal di Indonesia mempunyai hak dan kewajiban yang dimiliki oleh Warga Negara Asing selama tinggal di Indonesia sebagai berikut berhak atas segala perlindungan terhadap hak-hak asasinya termasuk hak perlindungan atas diri maupun harta benda yang dimiliki Warga Negara Asing tersebut, selama dalam proses yang resmi, berkewajiban untuk tunduk serta mematuhi segala ketentuan perundangan yang berlaku di negara Indonesia, tidak berhak untuk ikut serta dalam sebuah organisasi politik maupun instansi pemerintah, tidak berhak untuk ikut serta dalam sistem pemilu di Indonesia, baik untuk memilih maupun dipilih, dan tidak berkewajiban untuk ikut serta dalam program bela negara.

Dalam Pasal 1 angka 9 UU Nomor 6 Tahun 2011 Tentang Keimigrasian. Permohonan permintaan visa ini ditujukan kepada perwakilan Republik Indonesia di luar negeri atau kepada pejabat Republik Indonesia di tempat lain yang ditetapkan oleh pemerintah Republik Indonesia. Dalam Pasal 34 Undang-Undang Nomor 6 Tahun 2011 Tentang Keimigrasian, Visa terdiri atas Visa Diplomatik dalam Pasal 35 UndangUndang Nomor 6 Tahun 2011 Tentang Keimigrasian. Visa diplomatik diberikan kepada orang asing pemegang paspor dinas yang hendak bepergian ke negara Indonesia dengan tugas diplomatik. ${ }^{35}$ Visa Dinas dalam Pasal 36 Undang-Undang Nomor 6 Tahun 2011 Tentang Keimigrasian. Visa Dinas diberikan kepada orang asing yang pemegang paspor dinas yang akan bepergian ke negara Indonesia untuk menjalankan tugas dari pemerintah asing atau di utus Perserikatan Bangsa-Bangsa (PBB) yang tidak tugas diplomatik. $^{36}$

Visa Kunjungan dalam Pasal 38 Undang-Undang Nomor 6 Tahun 2011 tentang Keimigrasian. Visa Kunjungan dibagi menjadi 3 jenis, yaitu ${ }^{37}$ Visa Kunjungan Wisata; Diberikan kepada orang aisng yang hendak berkunjung ke negara Indonesia dengan tujuan untuk berwisata. Visa Kunjungan Usaha; Diberikan kepada orang yang hendak berkunjung ke negara Indonesia dengan maksud untuk melakukan usaha di bidang perdagangan, pertanian, perikanan dengan tujuan untuk bekerja menurut ketentuanketentuan hukum yang berlaku. Visa Kunjungan Sosial Budaya; Diberikan kepada orang asing yang hendak berkunjung ke negara Indonesia untuk keperluan kunjungan sosial budaya dan tidak termasuk kunjungan untuk wisata atau usaha.

Visa tinggal terbatas Pasal 39 Undang-Undang Nomor 6 Tahun 2011 tentang Keimigrasian, Visa Diam Sementara/Visa Tinggal Terbatas diberikan kepada orang

\footnotetext{
35 Ibid, hlm. 50.

36 Ibid.

37 Ibid, hlm. 51-52.
} 
asing tenaga ahli dengan tujuan bekerja serta istri dan anak-anaknya yang sah di bawah umur dan anggota keluarga yang kehidupannya menjadi tanggung jawab yang bersangkutan; Orang asing yang mengikuti pendidikan dan latihan atau melakukan penelitian ilmiah; Wanita asing dan anak di bawah umur yang akan menyertainya/ menyatuhkan diri dengan suami/ayah seorang warga negara Indonesia yang berdiam di Indonesia. Yang dimaksud dengan anak di bawah umur disini adalah anak yang masih berumur di bawah 16 (enam belas) tahun; Seorang bekas Warga Negara Indonesia yang kehilangan kewarganegaraan Republik Indonesia berdasarkan undang-undang kewarganegaraan. Visa ini berlaku paling lama 1 (satu) tahun, khusus untuk a dan b sedangkan untuk yang c dan d selama 6 (enam) bulan. Visa ini tidak berlaku lagi jika kedatangannya di Indonesia melebihi 3 (tiga) bulan terhitung sejak tanggal pemberian visa tersebut.

Warga Negara Indonesia, dalam kitab hukum Indonesia, salah satunya KUHAP tidak mengatur khusus mengenai apa syarat didengarkannya keterangan ahli dalam pemeriksaan di pengadilan. Adapun yang disebut dalam KUHAP adalah "selama ia (yang menjadi saksi ahli) memiliki 'keahlian khusus' tentang hal yang diperlukan untuk membuat terang suatu perkara pidana dan diajukan oleh pihak-pihak tertentu, maka keterangannya bisa didengar untuk kepentingan pemeriksaan”. Keahlian Khusus tersebut dapat diperoleh seseorang baik melalui pendidikan formal maupun nonformal, dan bisa juga melalui sertifikasi dalam bidang terkait keahlian serta pengalaman-pengalaman yang dimiliki.

Warga Negara Asing, menurut Debra Shinder, yang mengungkapkan beberapa faktor dan kriteria yang dapat digunakan sebagai syarat didalam menjadi saksi ahli, antara lain adalah : gelar pendidikan tinggi atau pelatihan lanjutan di bidang tertentu; Mempunyai spesialisasi tertentu; pengakuan sebagai guru, dosen, atau pelatih dibidang tertentu; lisensi Profesional, jika masih berlaku; ikut sebagai keanggotaan dalam suatu organisasi profesi; posisi kepemimpinan dalam organisasi tersebut lebih bagus; publikasi artikel, buku, atau publikasi lainnya, dan bisa juga sebagai reviewer. Ini akan menjadi salah satu pendukung bahwa saksi ahli mempunyai pengalaman jangka panjang; sertifikasi teknis; penghargaan atau pengakuan dari industri. ${ }^{38}$

Izin masuk adalah izin yang diterangkan pada visa atau surat perjalanan orang asing untuk memasuki wilayah Negara Republik Indonesia yang diberikan oleh Pejabat Imigrasi di tempat pemeriksaan. ${ }^{39}$ Pemberian izin masuk dilakukan dengan cara membubuhkan izin masuk pada Visa atau Surat Perjalanan orang asing yang bersangkutan. Pemberian izin masuk disesuaikan dengan jenis visa yang dimiliki oleh orang asing yang bersangkutan dan masa berlakunya pun disesuaikan dengan waktu izin keimigrasian yang dimiliki. Jenis-jenis Surat Perjalanan Republik Indonesia (Paspor) meliputi : paspor biasa; paspor untuk orang asing; surat perjalanan laksana

\footnotetext{
38 D. L. Shinder, "Testifying as an expert witness in computer crimes cases," techrepublic.com, Retrieved July 24, 2016 From http://www.techrepublic.com/blog/it-security/testifying-as-an-expertwitness-in-computer-crimes-cases/.

39 Ibid.
} 
paspor untuk warga negara indonesia; surat perjalanan laksana paspor untuk orang asing; paspor diplomat; surat perjalanan laksana paspor dinas; dan paspor haji. ${ }^{40}$

Surat perjalanan Republik Indonesia adalah dokumen resmi yang dikeluarkan oleh pemerintah Republik Indonesia yang memuat identitas pemegangnya dan berlaku untuk melakukan perjalanan ke luar negeri atau masuk ke wilayah Negara Republik Indonesia. Pemberian surat perjalanan Republik Indonesia/Paspor ini diberikan oleh menteri terkait dengan bidang tugas dan kewenangannya masing-masing. ${ }^{41}$ Dalam rangka penegakan hukum sekaligus menjaga kewibaan hukum, sebagai tidak lanjut dari pengawasan, khususnya pengawasan orang asing yang berada di wilayah negara Indonesia dan penangkalan keimigrasian, pada umumnya penindakan merupakan satu hal yang sangat penting dan harus dilaksanakan.

Pelaksanakan penindakan pelanggaran keimigrasian ini dapat dibedakan menjadi dua macam, yaitu tindakan keimigrasian dalam bentuk administratif; tindakan keimigrasian dalam bentuk tindak pidana keimigrasian secara legislasi/litigasi atau proses pengadilan. ${ }^{42}$ Pengertian tindakan keimigrasian adalah tindakan administratif dalam bidang keimigrasian diluar proses pengadilan. Dasar dari pelaksanaan tindakan keimigrasian dalam Undang-Undang Keimigrasian adalah melakukan kegiatan yang berbahaya atau patut diduga berbahaya bagi keamanan dan ketertiban umum, tidak menghormati atau menaati peraturan perundang-undangan yang berlaku.

Jenis sanksi tindakan keimigrasian, yaitu pembatasan, perubahan, atau pembatalan izin keimigrasian; larangan untuk berada di suatu tempat atau beberapa tempat tertentu di wilayah Indonesia; keharusan untuk bertempat tinggal di suatu tempat tertentu di wilayah negara Indonesia; pengusiran atau deportasi dari wilayah negara Indonesia; penolakan masuk ke wilayah negara Indonesia. ${ }^{43}$

\section{KESIMPULAN}

Permasalahan visa yang dialami oleh seorang ahli warga negara asing telah melanggar ketentuan keimigrasian, bahwa seorang ahli warga negara asing harus menggunakan visa izin tinggal terbatas bukan menggunakan visa kunjungan, hal ini jelas tidak sesuai dengan kapasitasnya sebagai seorang ahli yang dihadirkan di muka persidangan. Kekuatan alat bukti keterangan ahli bersifat bebas karena tidak mengikat hakim untuk memakainya. Hakim berpendapat bahwa keterangan ahli tersebut sah, meskipun bermasalah dengan visa keimigrasian. Seorang hakim hanya menilai keterangan ahli yang disampaikan di muka persidangan dan kewenangan hakim pula menggunakan keterangan ahli tersebut atau tidak tergantung pada keyakinan hakim. Hakim tidak boleh menjatuhkan pidana kepada seseorang hanya berdasarkan keyakinan saja, melainkan harus didukung dengan minimal dua alat bukti yang sah.

\footnotetext{
40 Ibid, hlm. 23.

41 Ibid.

42 Ibid, hlm. 70.

43 Ibid., hlm. 71.
} 
Seorang ahli warga negara asing dalam memberikan keterangan di muka persidangan dalam kondisi ia tidak mengurus visa berdasarkan Undang-Undang Keimigrasian yang berlaku, dapat dikatakan seorang ahli tersebut ilegal, karena seorang ahli melanggar ketentuan visa yang ada di dalam undang-undang keimigrasian, namun tidak berdampak kepada kekuatan kesaksiannya saat di muka persidangan dan mendapat tindakan keimigrasian berupa sanksi administrasi yaitu deportasi atau sanksi pidana, tetapi orang asing tersebut hanya melanggar ketentuan visa dan tidak dianggap membahayakan, maka seorang ahli warga negara asing hanya diterapkan sanksi administrasi keimigrasian sesuai dengan Pasal 75 ayat (2) Undang-Undang Nomor 6 Tahun 2011 tentang Keimigrasian.

\section{DAFTAR PUSTAKA}

Andi Hamzah, Pengantar Hukum Acara Pidana Indonesia Edisi Revisi, Ghalia Indonesia, Jakarta, 1985

Atang Ranoemihardja, hukum pidana, asas-asas hukum pidana, pokok pengertian \& teori serta pendapat para beberapa sarjana, pertanggungjawaban pidana atau kesalahan menurut hukum pidana terdiri dari 3 anasir yaitu pertama, dapat dipertanggungjawabkan dari si pembuat. Kedua, suatu sikap psikis pembuat berhubung dengan kelakuannya yaitu disengaja, dan sikap kurang hati-hati atau lalai. Ketiga, tidak ada alasan-alasan yang menghapuskan peratanggungjawaban pidana bagi pembuat (anasir pertanggungjawaban pidana), dan khusus anasir pertanggungjawaban ini berhubungan erat dengan "kesalahan" dan "melawan hukum" sebab tanpa melawan hukum tidak akan ada kesalahan, Tarsito, Bandung, 1984.

Didik Endro Purwoleksono, Hukum Acara Pidana, Airlangga University Press, Surabaya, 2015.

D. L. Shinder, "Testifying as an expert witness in computer crimes cases," techrepublic.com, Retrieved July 24, 2016 From http://www.techrepublic.com/ blog/it-security/testifying-as-an-expert-witness-in-computer-crimes-cases/

Hendar Soetarna, Hukum Pembuktian dalam Acara Pidana, Alumni, Cetakan Pertama, Bandung, 2011.

Hukumonline, Arti Cacat Hukum, http:/www.hukumonline.com/klinik/detail/ lt556fa8a2bl100/arti-cacat-hukum- diakses tanggal 11 Desember 2017, pukul 11.20 wib.

Jazim Hamidi \& Charles Christian, Hukum Keimigrasian Bagi Orang Asing di Indonesia, Sinar Grafika, Jakarta, 2015.

Lilik Mulyadi, Pembalikan Baban Pembuktian Tindak Pidana Korupsi, PT. Alumni, Bandung, 2013.

Mardjono Reksodipoetro, Sistem Peradilan Pidana Indonesia (Melihat kepada kejahatan dan penegakan hukum dalam batas-batas toleransi : Pidato Pengukuhan Penerimaan Jabatan Guru Besar tetap dalam Ilmu Hukum pada 
Fakultas Hukum Universitas Indonesia, Jakarta, 1993, hlm. 1 dalam buku Romli Atmasasmita, Sistem Peradilan Pidana Kontemporer, Kencana Prenada Media Group, Jakarta, 2010

M. Yahya Harahap, Pembahasan Permasalahan Dan Penerapan KUHAP Pemeriksaan Sidang Pengadilan, Banding, Kasasi, dan Peninjauan Kembali Edisi Kedua, Sinar Grafika, Jakarta, 2010.

Peter Mahmud Marzuki, Penelitian Hukum (Edisi Revisi), PT. Adhiya Andrebina Agung, Jakarta, 2015.

Romli Atmasasmita, Sistem Peradilan Pidana Kontemporer, Kencana Prenada Media Group, Jakarta, 2010.

S. Tanusubroto, Dasar-Dasar Hukum Acara Pidana Cetakan 2, Armico, Bandung, 1989.

Sihar Sihombing, Hukum Imigrasi, Nuansa Aulia, Bandung, 2009. 
114 | Keterangan Ahli Warga Negara Asing dalam Peradilan Pidana di Indonesia

This page is intentionally left blank 